\title{
Insurance Diversification and Total Risk
}

\author{
Tariq Alzoubi \\ School of Business, The University of Jordan, PO box 13368, Amman 11942, Jordan
}

\begin{abstract}
This paper investigates the effects of the diversification of insurance companies on their total risk by controlling size, capital and profitability on a sample, which includes all listed insurance companies in the Amman stock exchange for the period of 2009-2018. The results demonstrate that the diversification, size, capital ratio and profitability have a significant negative effect on total risk.
\end{abstract}

Keywords: insurance companies, diversification, total risk.

DOI: $10.7176 / \mathrm{EJBM} / 12-15-07$

Publication date:May $31^{\text {st }} 2020$

\section{Introduction}

This analysis investigates how the diversification of insurance types, as provided by insurance companies, can influence the total risk these companies are exposed to. Offering several types of insurance should assist insurance companies in reducing their total risk, as the resulting variety will act as a portfolio which should hedge overall risk, as suggested by the portfolio theory; losses from one type will be recovered by other types (Jordan et al., 2015).

In the majority of cases the effects of diversification are evaluated in respect of financial assets; however, this analysis will instead investigate the consequences of offering diverse forms of insurance on insurance companies' total risk. This will be achieved by posing the question of whether or not insurance companies are able to curtail total risk by diversifying the types of insurance they offer.

By considering the effects of diversification and controlling attributes such as company size, capital adequacy and profitability, this analysis will examine a sample of insurance companies from Jordan, utilising a fixed effects panel data analysis over the period from 2009 to 2018.

Jordan was selected as a sample for this study as there are over twenty-five insurance companies, all situated within a small country with a population of less than ten million, as of 2018, and a GDP of \$42 billion (World bank, 2019). Jordan is relatively modest in size, with multiple insurance companies operating in its competitive economy; as such, the example of Jordan is an intriguing case to study.

\section{Literature Review}

Available literature relating to the effects of diversification and risk in insurance is limited; the majority of studies available target the ramifications of diversification and the manner in which risk will be diminished from a financial perspective. A few papers were discovered which concentrated on diversification and risk in regards to a manufacturing enterprise.

The effects of diversification can further be considered as a determination of profitability for industrial enterprises and insurance companies. Analysis of a sample of 40 companies in Pakistan, over the period from 2005 to 2009, utilising a specialisation ratio to test the effects of diversification on performance, indicated that there is no relationship between diversification and performance (Iqbal et al., 2019). Investigating the effects of diversification on performance with a sample of 342 companies from Turkey, during the period from 2005 to 2009 , was not exclusive as the results presented an inverse U shape (Anil and Yigit, 2011). Taking a large sample of more than 6,000 observations over the period from 1995-2004, and analysing the effects of diversification on performance, the results demonstrated that diversification leads to a negative influence on profitability, measured by both ROA and ROE (Liebenberg and Sommer, 2008). In investigating the effects of diversification on performance on a sample with more than 7,000 observations, over the period from 1994-2002, the results indicated that there are substantial benefits emanating from product diversification, however these benefits are contingent on geographic diversification (Elango, 2008). Investigating the effects of diversification on profitability of Jordanian insurance companies, over the period from 2009-2016, resulted in the determination that diversification appears to have a positive effect on profitability (Alrabadi, 2019).

This analysis aims to bridge the distance between how the diversification of insurance types can influence the total risk of an insurance company.

\section{Data and Methodology}

The sample examined in this analysis includes all insurance companies listed in Amman stock exchange over the period of 2009-2018. This sample includes 27 companies, with a fixed effect panel data analysis having been used to analyse the data, by applying the following model: 
Where;

$$
\mathrm{Risk}_{\mathrm{it}}=\mathrm{B}_{1} \mathrm{DVF}_{\mathrm{it}}+\mathrm{B}_{2} \mathrm{SIZE}_{\mathrm{it}}+\mathrm{B}_{3} \mathrm{CAP}_{\mathrm{it}}+\mathrm{B}_{4} \mathrm{ROA}_{\mathrm{it}}+\varepsilon_{\mathrm{it}}
$$

Risk: is the total risk of insurance companies, measured as the variance of net income over the last three years, divided by total assets, to gauge a reasonable scale in terms of the independent variable of this research.

DVF: is the diversification of insurance types, which has been classified into three categories: HD (Highly diversified), MD (Moderately diversified) and UN (Undiversified), based on the specialisation ratio classification established by Rumelt (1982) (Rumelt, 1982).

SIZE: is the size of the insurance company, measured by the natural logarithm of the total assets.

CAP: is the capital adequacy, measured as total equity to total assets.

ROA: is the return on assets which reflects the firm's profitability, measured as net income after tax, divided by total assets.

\section{Results and analysis}

The results of the fixed effect model are presented in Table I, which reveals the results of HD, MD and UD models and how these varying levels of diversification can influence the total risk of insurance companies; taking into consideration control variables of size, capital adequacy and profitability.

Table 1: Regression results

Note: DVF: Diversification which includes three levels; HD: High diversification, MD: Moderate diversification, UD: Undiversified. SIZE: Company size, CAP: Capital adequacy, ROA: Return on assets (Profitability). ***, **, * indicate that coefficients are significant at the $1 \%, 5 \%$ and $10 \%$ levels, respectively.

\begin{tabular}{|l|c|c|c|}
\hline & HD & MD & UD \\
\hline DVF & $-0.0150 *$ & $0.0140 *$ & -0.0063 \\
\hline SIZE & $-0.0218^{*}$ & $-0.0222^{*}$ & $-0.0230 *$ \\
\hline CAP & $-0.0948 * * *$ & $-0.0936 * * *$ & $-0.0899 * * *$ \\
\hline ROA & $-0.1204 * * *$ & $-0.1209 * * *$ & $-0.1329 * * *$ \\
\hline Adjusted $\mathrm{R}^{2}$ & $51.95 \%$ & $51.98 \%$ & $51.35 \%$ \\
\hline F-Statistics & $7.6822 * * *$ & $7.6879 * * *$ & $7.5223 * * *$ \\
\hline Observations & 242 & 242 & 242 \\
\hline
\end{tabular}

The following conclusions can be drawn from the results indicated in Table I; firstly, there is an apparent negative relationship between high diversification and total risk, which confirms our expectations that these diversified insurance companies can reduce total risk by compensating any losses from one type with gains from others. Size, capital adequacy and return on assets, have significant negative repercussions on total risk; as size increases, companies become more capable of addressing risks as their assets provide security. Capital represents the final frontier for any company against risk, this is due to increases in the capital adequacy ratio resulting in decreases in total risk. Therefore, more profitable companies are better positioned to bear risks since they can generate funds internally to be used to offset various types of risk.

In relation to the moderate diversification model, it is clear that moderate diversification has a substantial positive effect on total risk; this result also confirms expectations that total risk increases with moderate diversification, while it decreases with high diversification. The results of control variables in this model are consistent with the outcomes of the high diversification model.

The undiversified model, however, presents insignificant outcomes in terms of DVF; implying that the total risk of undiversified enterprises will not be influenced and will, as a result, remain unchanged. Furthermore, in this framework, the results of control variables are compatible with high diversification and moderate diversification models.

All models demonstrate sound interpretive conclusions, with explanatory power of over $51 \%$ for each and significant corresponding F-statistic results.

This conclusive evidence suggests that diversification of the types of insurance provided can significantly reduce the total risk of an insurance company; furthermore, the size, increase in capital ratio, and the profitability of the company, can support the reduction of total risk.

\section{Conclusion}

This analysis aims to bridge the gap in literature by investigating the effect of diversifying insurance types on the total risk of insurance companies. Using Rumelt's specialisation ratio as a classification of diversification on a sample of 27 companies, which includes all insurance companies listed in the Amman stock exchange over the period from 2009 to 2018, is employed to illustrate this relationship, after controlling other variables including the company's size, its capital adequacy and profitability.

Using a fixed effect model, the results indicate that diversification is a significant variable in the reduction of the total risk to which insurance companies are exposed. Moreover, the larger the size, the more capital and the higher the level of profitability of an insurance company, will additionally reduce its total risk. 
The results of this analysis prompt recommendations for insurance companies to take active measures to increase diversification by offering a greater range of insurance types, as well as to increase their capital ratio, and ensure an adequate level of control over their costs and maximisation of revenue in order to boost profitability, and consequently decrease total risk exposure.

\section{References}

Alrabadi, S. (2019), Effect of Product Diversification on Firm Performance: Evidence from Insurance Companies in Jordan, Master Dissertation, the University of Jordan, Amman, Jordan.

Anil, I. and Yigit, I. (2011), The Relation between Diversification Strategy and Organizational Performance: A Research on Companies Registered to the Istanbul Stock Exchange. Market Procedia Social and Behavioral Sciences, 24, 1494-1509.

Elango, B. Yu-Luen, M. and Pope, N. (2008), An Investigation into the Diversification-Performance Relationship in the U.S. Property-Liability Insurance Industry. Journal of Risk and Insurance, 75(3), 567-591.

Iqbal, A. Hameed, I. and Qadeer, M. (2012), Impact of Diversification on Firms' Performance. American Journal of Scientific Research, 80, 42-53.

Jordan, B. Miller, T. and Dolvin, S. (2015), Fundamentals of Investments: Valuation and Management, (7th edition). New York: McGraw-Hill Education.

Liebenberg, A. and Sommer, D. (2008) Effects of Corporate Diversification: Evidence from the Property-Liability Insurance Industry. The Journal of Risk and Insurance, 75(7), 893-919.

Rumelt, R. (1982), Diversification Strategy and Profitability. Journal of Strategic Management, 3(4), 359-369.

Word bank, (2019). Jordan's Economic Update - April 2019. Available http://pubdocs.worldbank.org/en/837261553672494334/jordan-MEU-April-2019-Eng.pdf 